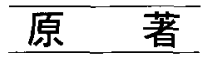

前庭神経炎症例に招ける健側耳の温度眼振反応の検討 松崎 真樹1) - 岩崎 真一22) - 牛尾 宗貴 22 ・室伏 利久 32

\title{
Caloric Responses of the Unaffected Ear of Patients with Vestibular Neuritis
}

\author{
Masaki Matsuzaki ${ }^{1)}$, Shinichi Iwasaki ${ }^{2)}$, Munetaka Ushio ${ }^{2)}$, Toshihisa Murofushi' ${ }^{3)}$ \\ ${ }^{1)}$ Department of Otolaryngology, Toshiba Hospital \\ ${ }^{2}$ Department of Otolaryngology, Faculty of Medicine, University of Tokyo \\ ${ }^{3}$ Department of Otolaryngology, Tokyo Postal Services Agency Hospital
}

We studied caloric responses of the unaffected side of patients with vestibular neuritis (VN). Six patients with VN, who underwent sequential caloric tests, were enrolled in this study. In all 6 subjects, the maximum slow phase eye velocity of caloric nystagmus on the unaffected side to ice water was smaller at the earlier stage after the vertigo attack (within one month after the attack) than that at the later stage. This phenomenon might be associated with the suppression of contralateral vestibular nuclei, which would be a part of vestibular compensation. We should take into consideration that caloric responses on the unaffected side could be altered according to the stage of the disease.

Key words: vestibular neuritis, vestibular compensation, caloric test, nystagmus

\section{はじめに}

前庭神経炎の診断には末梢前庭機能の高度低下 を証明する必要があり ${ }^{11}$ ，通常温度刺激検查が指 標とされている。ただし一側前庭機能急性低下時 には健常側にも前庭代償機構の影響が働くとされ て物り2〜4)，特に急性期以は健常側も正常時とは 異なる温度眼振反応を呈する可能性があると考兄 られる。左右の反応を相詨的に評価することが主 体である温度刺激検査に和いて健常側の反応に経 時的変化が生じるとすれば診断上大きな問題であ る。しかし前庭神経炎症例に和ける健側耳温度刺

\footnotetext{
i) 東芝病院耳鼻咽喉科

東京大学耳鼻咽喉科

東京逃信病院耳鼻咽喉科
}

激検查の推移について論じた報告は見当たらな い。

今回本研究の発端となった代表的症例を呈示す るとともに，他の前庭神経炎症例についても温度 刺激反応の経時的变化について検討を行った。

対象と方法

対象

東京遁信病院耳鼻咽喉科扣上び東京大学附属病 院耳鼻咽喉科めまい外来に打いて複数回の温度刺 激検査を施行し得た前庭神経炎 6 例（全員男性， 平均年齢50.8歳）を対象とした。前庭神経炎の診 断は，めまい診断の基準化のための資料に従っ だ。

万法

対象の健常側（最終的缊度眼振反応の高度低 
下を認めな's かった側）温度眼振（氷水 $20 \mathrm{ml}$, 20 秒注水) 最大緩徐相速度の経時的変化を検討し た（検榃時健常側向き自発眼振を認めた症例は， 便宜上緩徐相速度を健常側温度眼振最大緩徐相速 度に加算した)。

\section{結果}

まず，代表的症例を呈示する。

症例 : 56歳 男性

主訴：回転性めまい

既往歷：高血圧／発症時期不明の右難聴

現病歷: 平成15年10月 2 日昼食後, 特比誘因な く嘔気・嘔吐を伴う回転性めまいを発症。耳鳴・ 頭痛・構音障害・意識障害の随伴はなし。近医に て施行された頭部 CT に異常なく，同日夕東京遁 信病院耳鼻咽堠科比救急搬送された。初診時左向 目度の水平回旋混合性注視眼振を認め, 耳内所 見では右鼓膜に肥厚がみられたが急性炎症所見は なく，Weber test では右に偏した。外耳道王負荷 による瘦孔症状は認めなかった。構音障害・顔面 知覚障害などの第八脳神経領域以外の神経症状を 認めず，急性末梢前庭障害の疑いにて緊急入院と なった。入院翌日の純音聴力検査では右混合難聴 を認めたが，以前より難聴の自覚があり今回のめ まい発作時に增悪はないとのことであった（図 1)。頭部 MRI 検査では右乳突蜂巣に陳旧性炎 症を疑わせる陰影を認める以外異常を認めなかっ た。10月8日（第 7 病日）に氷水による温度刺激

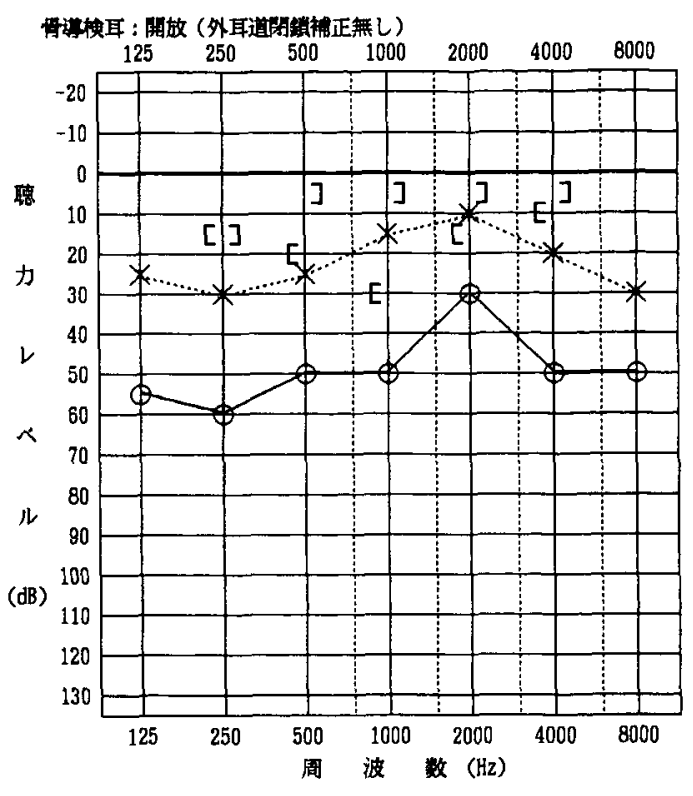

図 1 発症翌日の純音聴力検查結果 右混合難聴を認めたが，病歷拈よび画像所 見から陳旧性であると考えられた。

検查を施行したところ, 温度眼振最大緩徐相速度 が右側刺激時 $7^{\circ} / \mathrm{s}$ 儿対し左側刺激時 $3^{\circ} / \mathrm{s}$ (左向 き自発眼振 $3^{\circ} / \mathrm{s}$ あり）という結果であった（図 2 )。自発眼振の加減に上る補正を行らと半規管 麻疩 (CP) は右側20\%で，右耳の末梢前庭障書 は疑われたが両側の反応が不良であり，右側の高

\section{右側刺激}

\section{左側刺激}

$\underline{10 \mathrm{~s}}$

$\underline{10 s}$

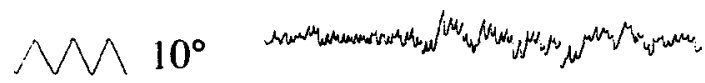

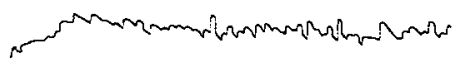

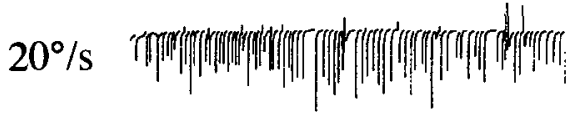

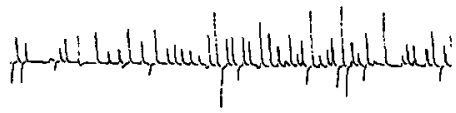

図 2 第 7 病日の温度刺激検查結果（水水 $20 \mathrm{ml}, 20$ 秒注水/反応最大時の拔粋）

温度眼振最大緩徐相速度は右側刺激時 $7^{\circ} / \mathrm{s}$ に対し左側 $3^{\circ} / \mathrm{s}$ であった。

自発眼振 $3^{\circ} / \mathrm{s}$ を補正すると CP は右20\%であった。 


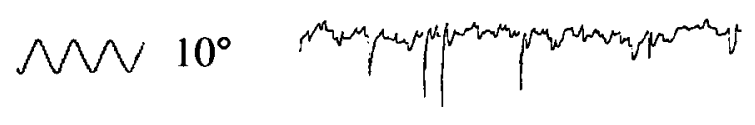
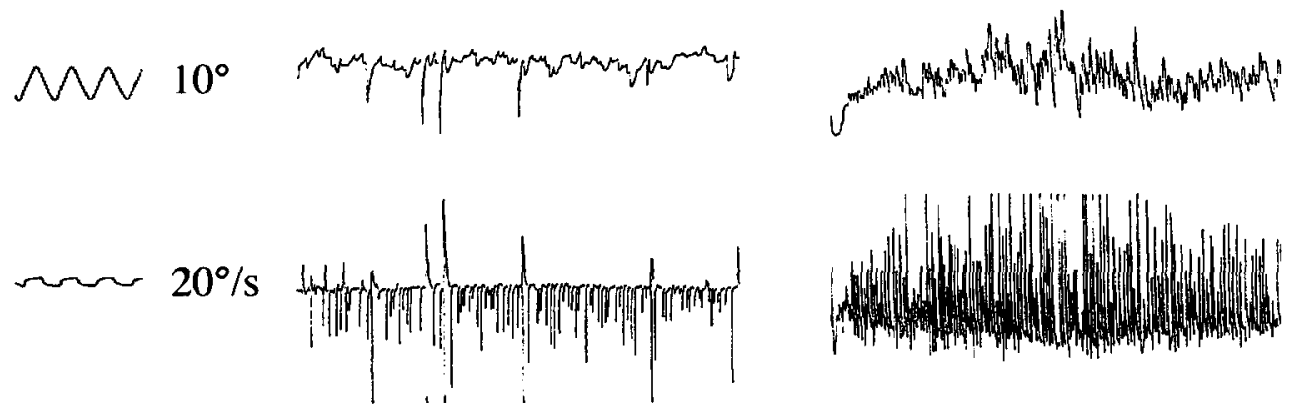

図 3 第 53 病日の温度刺激検查結果（水水 $20 \mathrm{ml}, 20$ 秒注水 / 反応最大時の抜粋） 左側の反応が前回と比べ良好となり，相対的に右の高度 CP が確認された。

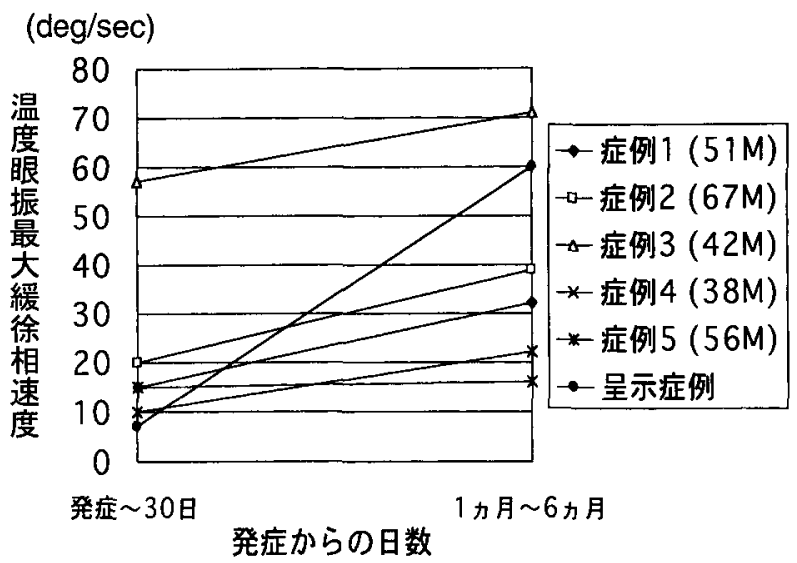

図4 前庭神経炎 6 症例记お江る健常側温度眼振最大緩徐相速度の経時変化

全例において，発症 30 日以内の最大緩徐相速度はその後の検査值上り小であった。

度低下とはいえなかった。自覚症状は徐々に回復 し，自発眼振も消失した状態で10月24日に退院と なった。第53病日に温度刺激検査を再施行したと ころ, 左側の最大緩徐相速度の増加が初回検査々 比べて著明であり, 結果として右側の高度 CP が 確認された（図 3)。外来に打ける経過観察中に めむい発作の再発はみられていない。

上記の症例に加之た前庭神経炎 6 例について検 討を行ったところ, 比較的病初期（発症 1 カ月以 内）の健常側の温度眼振最大緩徐相速度は 6 $57 \mathrm{deg} / \mathrm{sec}$ (中央値15）であり，その後発症 1 力 月以降 6 力月以内の検查では 16 71 deg/sec（中
央值35.5）であった（図 4)。この結果から発症 1 力月以降 6 力月以内の健常側の温度眼振最大緩 徐相速度は発症 1 力月以内の検査値より有意心大 きな值をとるものと推定された（Wilcoxon test， $p<0.05)$ 。一方，患側については 6 例全例が初回 検査では無反応または温度眼振最大緩徐相速度が $5 \%$ 未満であったのに対し，4例では 2 回目も変 化がみられず，2例では最大緩徐相速度がそれぞ れ $8^{\circ} / \mathrm{s} ， 16^{\circ} / \mathrm{s}$ と若干の改善を認めたのみであっ た。

\section{考察}

今回提示した代表的症例について，病初期の温 
度刺激検査で計算上上一側高度反応低下とならな かったのは主に健常側の温度眼振反応が不良で あったためである。

前庭神経核には Type I と Type II 22 種類の ニューロンが存在し相補的に作用している。Type

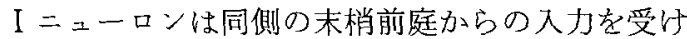
る興奮性ニューロンであるのに対し，Type IIは 抑制性ニューロンであり，交連線維を介する反対 側からの入力により発火する。例光ば回転刺激に より一側の前庭神経核が外側半規管から興奮性入 力を受ける場合，同時に反対側前庭神経核の抑制 性ニューロンにも興奮が生じるため，一側の興奮 と同時に対側には抑制がかかるしくみになってい る2)。一側末梢前庭機能が急速に低下した場合に は，患側から健常側への刘側抑制が消失するため， 健常側の前庭神経核ニューロンの活動はより六進 する。その結果逆に健常側から患側への対側抑制 が増強するため, 左右前庭神経核の活動性の不均 衡は増強され，急性期症状の増悪をきたすという 悪循環を生じる2゙ー4)。

これに対し前庭代償機構の一環として，日単位 の急性期には小脳片葉を中心とする中枢性抑制が 健常側前庭神経核儿加わり，左右前庭神経核の 不均衡が是正され急性期症状の緩和が図られる (neural adaptation)。一方，慢性期にはシナプス 発芽，神経伝達物質への感受性の変化などにより ネットワークの再構筑が図られ，前庭神経核の均 衡が維持される。これらにより，前庭神経炎に伴 ら急性期症状はたと文末梢前庭機能が回復しなく ても徐々に改善すると考克られている2゙市。

以上をふま兄て考察すると，今回是示した症例 では一側末梢前庭機能高度低下急性期に健常側前 庭神経核に比較的強い中枢性抑制が加わったた め, 初回の温度刺激検查では健側の温度眼振が抑 制され，結果として反応の左右差が減少した可能 性がある。一方，2度目の検查時には前庭代償の 慢性期に入り，健常側への抑制が解除されたため, 反応の左右差が明らかとなったと考光ることがで きる。

しかし本症例の結果のみでは初期に両側末梢前 庭機能の障害があり後に左側のみに回復がみられ た可能性，検查上の技術的問題などを否定でさな い。このため過去に複数回の温度刺激検查を施行 し得た前庭神経炎 5 例についても検討を行った。
結果として発症 1 力月以内の健常側の温度眼振最 大緩徐相速度はいずれも後に施行した検査值より 小であり，われわれの仮説を支持するものであっ た。

他に健常側の温度眼振反応に影響を与光る因子 として，中枢抑制作用のある薬物，被検者の覚醒 度などが挙げられる。例えばベンゾジアゼピン系 抗不安薬は健常側前庭神経核への抑制を増強する ことで急性期の抗めまい作用があるとされて和 $\eta^{5)}$ ，投与時には温度刺激検查の結果が修飾され る可能性がある。また，急性めまいに対する自律 神経反射が強い場合には検查時の覚醒度が低下し て温度眼振反応が不良となる場合もありらる。今 回検討した 6 例では検查時に中枢抑制作用のある 薬物は投与されて招らず，検查中には検者が頻回 に声をかけることにより被検者の覚醒を保つよう にしているため，こらした因子の影響はないもの と考えられる。

もら一つの可能性として急性期に健常側に向か 万眼振方向優位性がみられた場合，健常側への冷 刺激に対する患側方向の眼振が減弱するため，温 度眼振の左右差が減少すると考光られる。この場 合健常側の反応低下を確認するには温刺激子併施 する必要があるが，今回は retrospective に検討 を行ったため冷刺激のみの結果となった。当科で は検查時問の延長，患者への負担などから冷温交 互刺激は通常行っていないが，前述のような疑い がある場合には温刺激の追加も必要であると思わ れた。また，泠刺激のみの補正に際し，単純な自 発眼振緩徐相速度の加減が適切であるかてついて も検討が必要である。

前庭神経炎の経過中に健常側の温度眼振反応に 経時的変化があるとすると，相対評価による温度 刺激検查を施行するにあたりその適正時期が問題 となる。ネコ老用いた寒験報告では前庭神経核の 静止電位は一側内耳破壞後 2 日目では両側とも silent であるが，1 週間目では非施術側に回復の 徵候がみられる。1カ月後の测定では两側とも full activity となるが，この急性期に扣的る非施術 側への抑制は小脳片葉室破壊することにより解除 されるとい5（脱代償）。无ルモットでは内耳 破壊後非施術側の前庭神経核電位の回復に数日を 要するとされわ，ラットを用いた報告では内耳破 壊後 2 週間以上になると小脳片葉を破壊しても脱 
代償はもはや生じないとされている3)。

ヒトの場合一側末梢前庭機能急性堒失後の注視 眼振の消失には約 1 週間かかるといわれるが2), 前庭神経炎症例の自発眼振を長期観察した報告で は7 日〜 2 年以上と個人差が非常に大さいとい 58)。また，ダンタマイシン鼓室内注入後の自発 眼振消失についての報告では21日〜120日（中央 值35日）されている9)。ヒトに和ける前庭代償過 程での健常侧への中枢性抑制の持続時間に関する 報告は得られなかったが，他の哺乳類上り個体差 が大きい可能性がある。あるいは今回検討した健 側耳の温度眼振反応の経時的変化がヒトの場合の 中枢性抑制の指標となる可能性もあると思われ る。

突発性めまい症例を温度刺激検查で CP 陽性例 と陰性例に分けて検討した報告では，それぞれ臨 床経過と臨床背景が共通しており別の疾患とは考 えにくい場合もあるとされている10\}。類似の機序 による末梢前庭障害でも外側半規管系の機能低下 の有無で前庭神経炎の診断から除外されてしまう ことから診断基準の問題点を指摘する意見もあ $\eta^{10)}$, 外側半規管機能が温存されながら後半規管 系に障害をきたした症例の報告もある11)。しかし 健常側前庭神経核への中枢性抑制とい5観点によ れば，発病初期の検査で CP 陰性の場合でも再検 査により前庭神経炎の診断基準に合致する症例も 存在するのではないかと考えられる。

1987年めまいの診断基準化委員会による前庭神 経炎の診断基準では「ときに両側性のものもあ る」とあるため1), 厳密には一側のみの CP は必 須ではないが, 両側前庭神経炎は非常に稀である。 また, 小脳梗塞, 多発性硬化症などの中枢疾患で 蝸牛症状を伴わない回転性めまいのみを呈した症 例の報告もあり ${ }^{12}$, 温度刺激検査の左右差は前庭 神経炎のみならず末梢前庭疾患の鑑別・予後診断 において非常に重要である。

結論として，急性めまい症例儿おいて温度刺激 検查の結果有意な左右差が得られなかった場合で 己一側末梢前庭 (半規管) 障害が疑わしい症例に は経時的に再検查を行う，または head impulse test $^{13)}$ など左右比を用いない検查法の併用が必要 であると考兑られた。

\section{まとめ}

1. 発症早期の温度刺激検查で高度な左右差を
認めず，後日再検查にて一側高度 $\mathrm{CP}$ が確認され た前庭神経炎症例について報告した。

2.上記の症例含めた前庭神経炎症例 6 例に おける健常側の温度眼振反応の経時変化について retrospective に検討したところ，全例に扣いて病 初期の方が健常側刺激の最大緩徐相速度が後の検 查より小さい傾问を認めた。

3.この機序と乙て比較的病初期には健常側前 庭神経核に中枢性抑制が加わっている可能性を考 察した。

4. 前庭神経炎の確定診断目的に温度刺激検查 を行らにあたり，病初期に䖳いては温度眼振反応 の左右差がみか子上小さくなる可能性があるた め，末梢前庭 (半規管) 障害が疑わしい症例につ いては経時的再検査が必要であると考えられた。

本論文の内容は第63回日本めまい平衡医学会 （2004年，高崎市）にて発表した。

\section{文献}

1）小松畸篤，二木 隆，原田康夫，他：めまい の診断基準化のための資料 6 . 前庭神経炎. Equilibrium Res 47: 255-256, 1988

2 ) Curthoys IS, Halmagyi GM: Vestibular compensation. Adv Otorhinolaryngol 55: 82-110, 1999

3）北原 糺：前庭代償. Equilibrium Res 59: 103-111, 2000

4) 山中敏彰 : 前庭代償の薬理. Equilibrium Res 59: 543-555, 2000

5 ）北原 糺, 武田憲昭, 肥塚 泉, 他：めまい に対するブロマゼパムの治療効果. Equilibrium Res 57: 401-407, 1998

6) McCabe BF, Ryu JH: Experiments on vestibular compensation. Laryngoscope 79: 17281736, 1969

7) Smith PF, Curthoys IS: Neuronal activity in the contralateral medial vestibular nucleus of the guinea pig following unilateral labyrinthectomy. Brain Res 444: 295-307, 1988

8）一條宏明，秋田二朗，石井賢治，他：前庭神 経炎の長期観察. 日耳鼻会報 99: 306-313， 1996

9 ) Takai Y, Murofushi T, Ushio M, et al: Recovery of subjective visual horizontal after unilateral 
vestibular deafferentation by intratympanic instillation of gentamicin. J Vestib Res 16: 69-73, 2006

10）武田憲昭, 肥塚 泉, 河野幹子, 他：前庭神 経炎の診断扣よび治療に扣ける問題点一突発 性めまい症例の臨床的検討からの考察一，日 耳鼻会報 98: 951-958, 1995

11) Halmagyi GM, Aw ST, Karlberg M, et al: Inferior vestibular neuritis. Ann N Y Acad Sci 956: 306-313, 2002

12) Disher MJ, Telian SA, Kemink JL: Evaluation of acute vertigo: unusual lesions imitating vestibular neuritis. Am J Otol 12: 227-231, 1991

13) Black RA, Halmagyi GM, Thurtell MJ, et al: The active head-impulse test in unilateral peripheral vestibulopathy. Arch Neurol 62: 290293,2005

原稿到着：平成18年 7 月 20 日

別刷請求先 : 松崎真樹

₹140-0014 東京都品川区東大井6-3-22

東芝病院耳鼻咽喉科 